\title{
Efecto que el tipo de cemento y la dosificación del mortero ejercen en la velocidad de corrosión de armaduras embebidas en mortero carbonatado
}

\author{
Effect of cement type and cement proportion \\ in the corrosion rate of rebars \\ embedded in carbonated mortar
}

Fecha de recepción: 17/II/87
C. ALONSO y C. ANDRADE IETCC/CSIC

Serrano Galvache, s.n. 28033 -Madrid/España

\section{RESUMEN}

La inexistencia de datos cuantitativos sobre el comportamiento del acero en morteros y hormigones carbonatados ha llevado a la realización de una serie de ensayos para conocer las cinéticas de corrosión de las armaduras. Como técnica de medida se ha utilizado la determinación de la Resistencia de Polarización.

En los presentes ensayos se ha realizado un primer estudio con mortero para conocer la influencia de la naturaleza del cemento, la proporción del mismo y la relación agua/cemento $(\mathrm{a} / \mathrm{c})$ en la velocidad de corrosión del acero.

Los resultados indican que el tipo de cemento no ha presentado una tendencia sistemática que sea digna de resaltar, por lo que no parece que la naturaleza del mismo influya significativamente en la velocidad de corrosión. En cambio, sí parece afectar más significativamente la dosificación del cemento (cuanto más elevada menos corrosión se detecta) y la porosidad o compacidad del mortero que influye en el sentido lógico de más protector el mortero cuanto más compacto y más impermeable resulte.

\section{SUMMARY}

The inexistence of quantitative data on steel behaviour in carbonated mortar and concrete have driven us to carry out a serie of tests to know the kinetic of the corrosion rebars.

Polarization Resistance was the technique used to determine the corrosion rate of the rebars.

In the present tests a first study with mortar has been carried out to know the influence of the cement nature, its proportion and water-cement $(W / c)$ ratio on the steel corrosion rate.

The results indicate that the type of cement has not a significant influence, non a systematic trend in the corrosion rate measured.

On the contrary the cement proportion seems to have a more important effect (the higher the cement dosage $\mathrm{c} / \mathrm{s}$, the lower the corrosion is).

\section{INTRODUCCION}

El fenómeno de la carbonatación del hormigón y su incidencia en el proceso de corrosión de las armaduras es uno de los temas que más ha empezado a preocupar en los últimos años (1) (2) debido a las desfavorables consecuencias que ésta tiene sobre la durabilidad de las estructuras de hormigón armado.

Al reaccionar el $\mathrm{CO}_{2}$ atmosférico con los productos hidratados del cemento se produce un fuerte descenso del $\mathrm{pH}$ en la solución de

\section{INTRODUCTION}

The phenomenon of the carbonation of the concrete and its effect on the corrosion process of the rebars is one of the subjects which has produced more concern in the lasts years (1) (2), due to the unfavourable consequences that this carbonation has on the durability of the concrete structures.

When atmospheric $\mathrm{CO}_{2}$ reacts with the hydrated products of the cement, a $\mathrm{pH}$ decrease of the pore concrete solution (3) 
los poros del hormigón (3) que desencadena la corrosión de las armaduras.

Cuando el frente carbonatado alcanza la armadura durante el tiempo de vida útil para el cual la estructura fue proyectada, ésta se empieza a corroer de forma generalizada originando una paulatina disminución de sección y un posible agrietamiento del recubrimiento de hormigón.

Los parámetros inherentes a la naturaleza del hormigón (proporción de cemento por $\mathrm{m}^{3}$, relación $\mathrm{a} / \mathrm{c}$, etc.) han sido estudiados a nivel de laboratorio (4) (5) para conocer su influencia en la velocidad de carbonatación.

En el presente trabajo se aportan una primera serie de resultados sobre la influencia en la velocidad de corrosión (calculada mediante medidas de resistencias de polarización) del tipo de cemento empleado en la fabricación del mortero, la dosificación de cemento y la relación a/c.

\section{METODO EXPERIMENTAL}

\section{Materiales}

Se fabricaron probetas de mortero de $2 \times 5,5 \times 8 \mathrm{~cm}$ con seis tipos de cementos: P-450 ARI, P-350 Y, P + $30 \%$ cenizas, S-II 350, PUZ 350 y cenizas; cuya composición química se da en la Tabla I. La relación $\mathrm{c} / \mathrm{a}$ y a/c utilizada en estos casos fue $1 / 3$ y 0,5 respectivamente.

Se preparó también otra serie de probetas de las mismas dimensiones que las anteriores con los cementos P-450 ARI y P-350 Y, pero de distintas dosificaciones: $\mathrm{c} / \mathrm{a}=1 / 2 \mathrm{y}$ $a / c=0,5 ; c / a=1 / 5$ y $a / c=0,5 ; c / a=1 / 3$ y $a / c=0,4 ; c / a=1 / 3$ y $a / c=0,7$.

Todas las probetas ensayadas se curaron en una atmósfera del $90 \%$ de H.R. $\pm 2^{\circ} \mathrm{C}$ y seguidamente a la atmósfera con una humedad alrededor del $50 \%$. Posteriormente se carbonataron en una cámara saturada de $\mathrm{CO}_{2}$ con una humedad del $60 \%$.

Finalmente se sometieron a ciclos de humedad-secado $(100 \%, 50 \%$ y parcialmente sumergidas P.S.) con una duración de las mismas entre 15 días y 2 meses.

Las probetas tenían embebidas dos barras idénticas de acero corrugado y otro redondo de grafito utilizado como electrodo auxiliar en las medidas electroquímicas de control de la corrosión. takes place and the corrosion of the rebars starts.

When the carbonated front reachs the steel, during the life time for which the structure was projected, the rebar starts corroding in a generalized way, producing a loss of cross section area of the steel and a possible cracking of the concrete cover due to the expansive oxydes formed.

The most representative parameters in a concrete (amount of cement by $\mathrm{m}^{3}, \mathrm{w} / \mathrm{c}$ ratio, etc.) have been studied in laboratory (4) (5) to know their influence on the carbonation rate.

On the present work a first serie of results about the influence of the cement type, the cement proportion in the mortar and the $\mathrm{w} / \mathrm{c}$ ratio on the corrosion rate (calculated by polarization resistance) are given.

\section{EXPERIMENTAL}

\section{Material}

Mortar specimens of $2 \times 5.5 \times 8 \mathrm{~cm}$ size were made with six types of cements: OPC, SRPC, SC, POZZ C, OPC + $30 \%$ FAC and FAC, their chemits composition are given in Table $I$.

The $c / s$ and $w / c$ ratios used in these cases were $1 / 3$ and 0,5 respectively.

A new set of specimens on the same size than previous ones were also made with the cements OPC and SRPC. Using differents cement proportions: $c / s=1 / 2$ and $w / c=0.5$, $c / s=1 / 5$ and $w / c=0.5, c / s=1 / 3$ and $w / c=0,4, c / s=1 / 3$ and $w / c=0.7$.

All the specimens were cured in a chamber with $90 \%$ of R.H. $\pm 2^{\circ} \mathrm{C}$ and after in $50 \%$ of R.H. Later the specimens were carbonated in a chamber saturated in $\mathrm{CO}_{2}$ and $60 \%$ of R.H.

Finally they were kept at wet and dry humidity periods $(100 \%, 50 \%$ and Partial Immersion P.I.) for 15 days or 2 months.

The specimens had embedded two identical bars of corrugated steel as working electrodes, and a counter graphite electrode to make electochemical measurements. 
TABLA I

\begin{tabular}{|c|c|c|c|c|c|c|}
\hline $\begin{array}{l}\% \text { Cementos } \\
\text { Cements }\end{array}$ & $\begin{array}{l}\text { P-450 ARI } \\
\text { O.P.C. }\end{array}$ & $\begin{array}{l}\text { P-350 Y } \\
\text { S.R.P.C. }\end{array}$ & $\begin{array}{c}\text { P+ } 30 \% \text { Cenizas } \\
\text { O.P.C. }+30 \% \text { F.A.C. }\end{array}$ & $\begin{array}{l}\text { S-1I } 350 \\
\text { S.C. }\end{array}$ & $\begin{array}{l}\text { PUZ } 350 \\
\text { Pozz. C }\end{array}$ & $\begin{array}{l}\text { Cenizas } \\
\text { F.A.C. }\end{array}$ \\
\hline P.F./L.I. & 6,83 & 2,6 & 1,9 & - & 4,2 & 0,8 \\
\hline R.I./Insol. & 1,06 & 1,4 & 16,2 & 0,3 & 3,1 & 28,4 \\
\hline $\mathrm{SiO}_{2}$ & 17,84 & 20,8 & 21,8 & 25,1 & 23,6 & 17,6 \\
\hline $\mathrm{Al}_{2} \mathrm{O}_{3}$ & 5,00 & 4,1 & 6,0 & 8,3 & 6,3 & 6,1 \\
\hline $\mathrm{Fe}_{2} \mathrm{O}_{3}$ & 3,20 & 4,4 & 3,2 & 2,3 & 4,0 & 3,6 \\
\hline $\mathrm{CaO}$ & 59,80 & 61,7 & 44,8 & 53,9 & 50,6 & 40,2 \\
\hline $\mathrm{MgO}$ & 1,70 & 2,0 & 2,1 & 5,3 & 3,8 & 0,8 \\
\hline $\mathrm{SO}_{3}$ & 3,22 & 2,2 & 3,0 & 2,9 & 3,1 & 2,2 \\
\hline $\mathrm{CaO}$ libre/Free & 0,76 & 0,6 & 0,4 & 1,8 & 0,8 & 0,6 \\
\hline $\mathrm{Na}_{2} \mathrm{O}$ & 0,16 & 0,24 & 0,1 & 0,17 & 0,41 & 0,14 \\
\hline $\mathrm{K}_{2} \mathrm{O}$ & 0,83 & 0,54 & 0,68 & 0,82 & 0,91 & 0,34 \\
\hline $\mathrm{S}^{=}$ & - & - & - & 0,4 & - & - \\
\hline $\mathrm{MnO}$ & - & - & - & 0,4 & - & - \\
\hline $\mathrm{CO}_{2}$ & - & - & - & 0,1 & - & - \\
\hline $\mathrm{H}_{2} \mathrm{O}$ comb. & - & - & - & 0,4 & - & - \\
\hline
\end{tabular}

\section{Técnicas}

La estimación de la intensidad de corrosión de las armaduras se realizó mediante la determinación de la resistencia de polarización y empleando la ecuación de Stern y Geary (6) la forma de aplicar esta técnica al hormigón ya se explicó en trabajos previos (4) (7).

\section{Techniques}

Polarization resistance determination to stimate the corrosion intensity of the rebars was used. Stern and Geary (6) equation was employed $i_{\text {corr }}=B / R_{p}$, the way to use the $R_{p}$ technique in concrete was explained in previous paper (7) (8) (9).

$$
\mathrm{i}_{\text {corr }}=\mathrm{B} / \mathrm{R}_{\mathrm{p}}
$$

Los valores de la cte $B$ usados fueron de $26 \mathrm{mV}$ cuando los redondos exhibían una alta intensidad de corrosión y 52 para condiciones de pasivación.

El dato de pérdida de peso electroquímica se calculó al aplicar la ley de Faraday a la
The values of the constant $B$ were $26 \mathrm{mV}$ when the rebars had significant corrosion intensities and $52 \mathrm{mV}$ for no significant corrosion conditions.

The electrochemical weight loss was calculated from Faradays law. 
intensidad de corrosión total del proceso, obtenida al integrar la curva $\mathrm{i} \rightarrow \mathrm{t}$.

\section{RESULTADOS}

La evolución de las variables $E$ e intensidad de corrosión de las armaduras durante el proceso de carbonatación de los morteros en los que estaban embebidos fabricados con los seis tipos de cementos anteriormente mencionados, se presentan en la parte superior y media de la figura 1.

Se observa en todos los casos, ya a los pocos minutos de iniciarse la carbonatación, un aumento de la $i_{\text {corr }}$ que llega incluso a alcanzar valores de $5 \mu \mathrm{A} / \mathrm{cm}^{2}$ en algunos casos

(S-II 350). Simultáneamente tiene lugar un descenso del potencial hacia valores más negativos $\left(\simeq-500 \mathrm{mV}_{\mathrm{SCE}}\right)$.

Esto es debido a que el $\mathrm{pH}$ de la disolución de los poros desciende y se produce la ruptura de la capa pasiva.

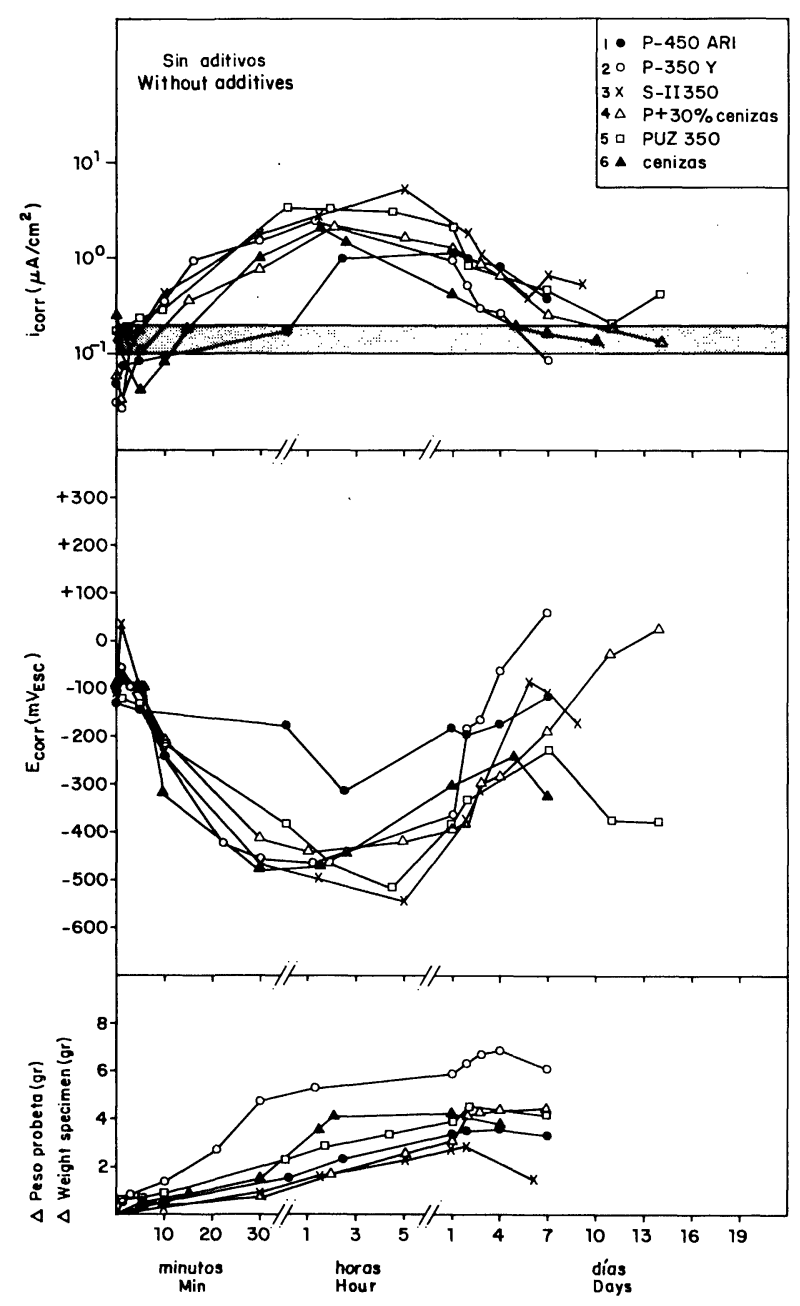

Tiempo durante la carbonatación-carbonatación time.

\section{RESULTS}

The evolution of the $E_{\text {corr }}$ and $i_{\text {corr }}$ of the rebars during the carbonation process of the mortars, made with the six types of cements previously named, are given in parts (a) and (b) in figure 1.

The figure shows that with all cement after few minutes of the carbonation starting, the $i_{\text {corr }}$ increases and reachs values even about $5 \mu \mathrm{A} / \mathrm{cm}^{2}$ in some cases SC.

Simultaneously a potential decreasing to more negative values $\left(\simeq-500 \mathrm{mV} \mathrm{V}_{\text {SSCE }}\right)$ takes place.

This behaviour is due to the $\mathrm{pH}$ of the pore concrete solution falls and the dissolution of the passive film is initiated.

Fig. 1.-Control de los cambios de la $i_{\text {corr }}$ (a) $E_{\text {corr }}$ (b) y peso de la probeta (c) durante la carbonatación acelerada de mortero amasado con los cementos: 1) P-450 ARI, 2) P-350 Y, 3) S-II-350, 4) P + $30 \%$ cenizas, 5) PUZ-350 y 6) cenizas.
Fig. 1.-Evolution of the $i_{\text {corr }}$ (a) $E_{\text {corr }}$ (b) and specimen mortar weight (c) during an acelerated carbonation process of mortar made with: 1) OPC, 2) SRPC, 3) SC, 4) $O P C+30 \%$ FAC, 5) POZZC, and 6) FAC 
El avance de la carbonatación se controla por el aumento de peso que se produce en las probetas (parte inferior, figura 1), al formarse $\mathrm{CaCO}_{3}$ y $\mathrm{H}_{2} \mathrm{O}$. Cuando el peso de la probeta se mantenía constante o descendía se consideró como una indicación del final de la carbonatación. Es de resaltar que en ese
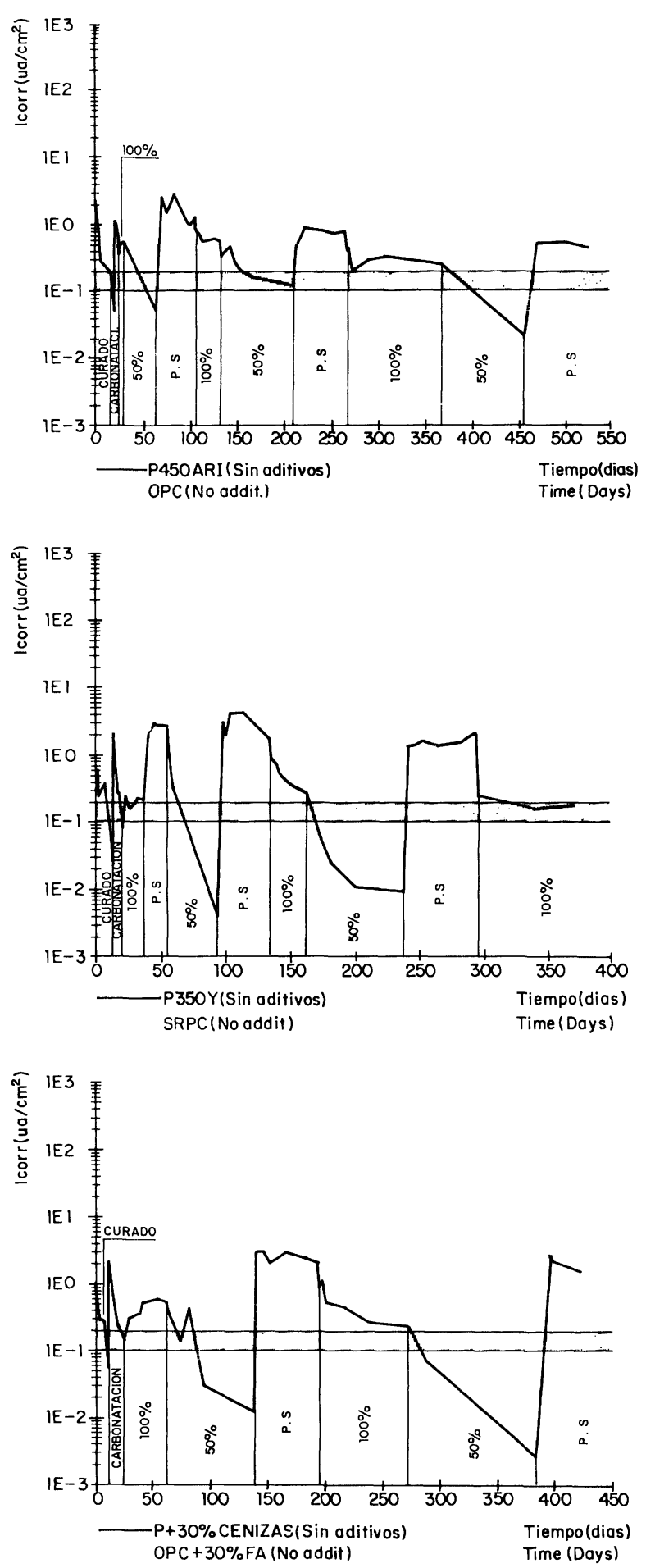

Fig. 2.-Evolución de la $i_{, \ldots, r}$ en función del tiempo de armaduras embebidas en mortero carbonatado amasado con 6 tipos de cementos y $\mathrm{c} / \mathrm{a}=1 / 3 ; \mathrm{a} / \mathrm{c}: 0.5$. Efecto de la humedad (100\%, $50 \%$ y P.S.).
The carbonation evolution is determined by the weight increasing which the specimens suffer (figure 1 part c), when $\mathrm{CaCO}_{3}$ and $\mathrm{H}_{2} \mathrm{O}$ are formed. When the specimens reach a constant weight or it decreases, this was consider as an indication of the end of the carbonation process. At that moment as $E_{\text {corr }}$ as the $i_{\text {corr }}$
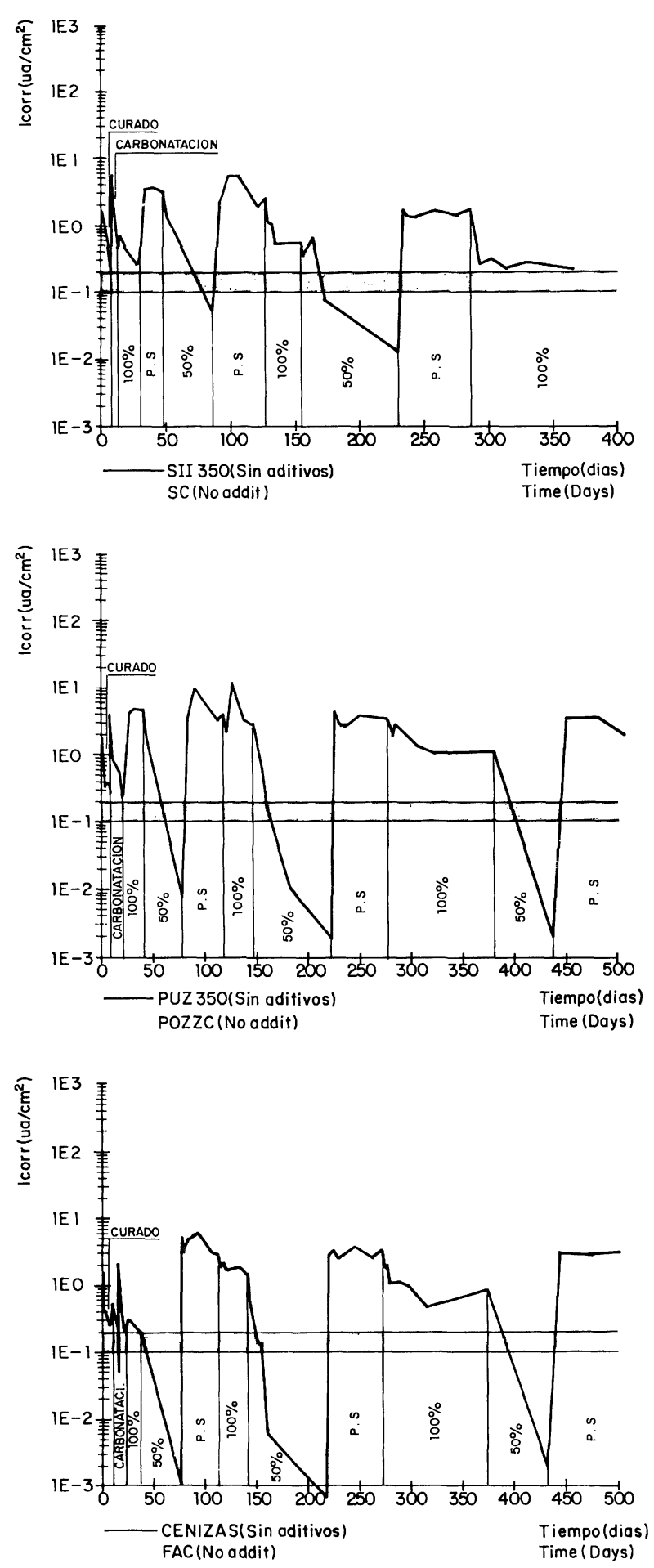

Fig. 2. $-i_{c o r r}$ as a function of time of rebars embedded in carbonated mortar made with different types of cements and $\mathrm{c} / \mathrm{s}=1 / 3 . \mathrm{w} / \mathrm{c} \cdot 0.5$. Effect of the humidity $(100 \mathrm{o} / \mathrm{s}$, $50 \%$ and P.I.) 
momento tanto el potencial como la intensidad comienzan a evolucionar en sentido contrario al mostrado durante la fase inicial de la carbonación.

Durante la conservación de las probetas en ciclos de humedad-secado, las humedades bajas $(50 \%)$ siempre provocaron velocidades de corrosión muy bajas, independiente del tipo de cemento con qué se fabricó el mortero (figura 2).

Al incrementarse la humedad ambiental, la velocidad de corrosión lógicamente aumenta, siendo máxima cuando se encuentran las probetas en condiciones de inmersión parcial, llegando en algunos casos a alcanzar velocidades de corrosión entre 1 y $10 \mu \mathrm{A} / \mathrm{cm}^{2}$.

Se confirma nuevamente con estos resultados que la carbonatación por sí sola, no supone un riesgo para las armaduras, más que cuando hay suficiente humedad en los poros del hormigón.

En cuanto al supuesto de que distintos tipos de cementos puedan generar diferentes velocidades de corrosión sobre las armaduras, el único hecho digno de resaltar es el mayor nivel de corrosión que presentan las armaduras embebidas en el mortero carbonatado amasado con los cementos PUZ-350 o cenizas. Con los demás cementos no se han encontrado diferencias sistemáticas. Esto último se aprecia mejor en la figura 3, donde se dan los valores de $i_{\text {corr }}$ a los 30 días de permanecer en una humedad.

En los ensayos para comprobar el efecto de la dosificación del mortero en la velocidad de corrosión se apreció, por una parte, similar comportamiento al ya descrito frente a la humedad y, por otra, se comprobó como al aumentar el contenido en arena del mortero la velocidad de corrosión de las armaduras, en las condiciones P.S., era superior mientras que ésta se hacía muy pequeña al disminuir la humedad de los poros. Como se puede deducir de lo presentado en la figura 4.

El efecto que ambas variables, tipo de cemento y dosificación del mortero, han tenido en la velocidad de corrosión de armaduras embebidas en mortero carbonatado se aprecia más claramente en las figuras 5 y 6 , donde se ha representado la pérdida de peso electroquímica sufrida por el acero para cada condición de ensayo.

Las mayores pérdidas de peso se dieron para los aceros embebidos en las probetas fabricadas con los cementos PUZ 350 y cenizas, asi como para las dosificaciones: start changing towards the opposite direction shown since the beginning of the carbonation.

Held the specimens to differents drying and wetting periods, was proved that low humidities, as $50 \%$ is, always provoked low values of corrosion rate, without consider the type of cement with which the mortar was made, as it is shown in figure 2.

When the humidity increases the corrosion rate of the rebars also increases and this last one reaches the highest value when the specimens are under partial immersion (reaching in some cases values between 1 and $10 \mu \mathrm{A}\left(\mathrm{cm}^{2}\right)$.

From these results it is stated again, that only carbonation is dangerous for rebars when enough humidity in the pores of the concrete exits.

The attack suffered by the rebars was uniform and generalized, although some localized zones presented more important damage. The oxides were brown in colour but some points presented also a darker aspect even until black colour.

Concerning to the different cements studied, the only fact to point out is the slightly higher level of corrosion that rebars embedded in carbonated mortar made with pozzolan or fly ash cements have. This trends is better appreciated in figure 3 . Where the $i_{\text {corr }}$ values after 30 days stay of the specimens in each humidity are given.

When different cement proportions were employed it was observed that when the amount of aggregate increased the corrosion rate of the rebars under P.I. did, but they became very low when the humidity decreased. In figure 4 is shown this behaviour.

However the influence that both variables, type of cement and cement proportion in mortar, have had in the corrosion rate of rebars embedded in carbonated mortar is more clearly appreciated in figures 5 and 6, where the electrochemical weight loss is represented.

The highest weight loss was found for the steels embedded in the specimens made with the cements pozzolan or fly ash, and for the proportions $(c / s=1 / 5$ and $w / c=0.5)$, 
$c / a=1 / 5$ y $a / c=0,5$ y $c / a=1 / 3$ y $a / c=0,4$ y $c / a=1 / 3$ y $a / c=0,7$.

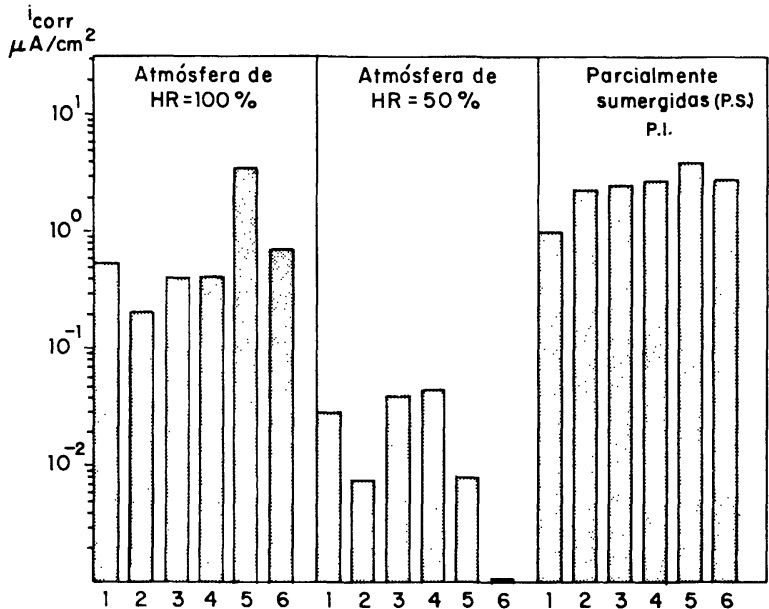

Mortero carbonatado sin aditivos (a los 30 días de conservación por humedad).

Fig. 3. - $\mathrm{i}_{\text {or }}$ tomada por las armaduras después de la carbonatación, y a los 30 días de permanecer en cada humedad: 1) P-450 ARI, 2) P-350 Y, 3) P + $30 \%$ cenizas, 4) S-II 350,5$)$ PUZ 350 y 6) cenizas.

$i_{\text {corr }}$ of rebars in carbonated mortar after 30 days of the specimens in each humidity: 1) OPC, 2) SRPC, 3) OPC + $+30 \%$ FAC, 4) SC, 5) POZZC, 6) FAC

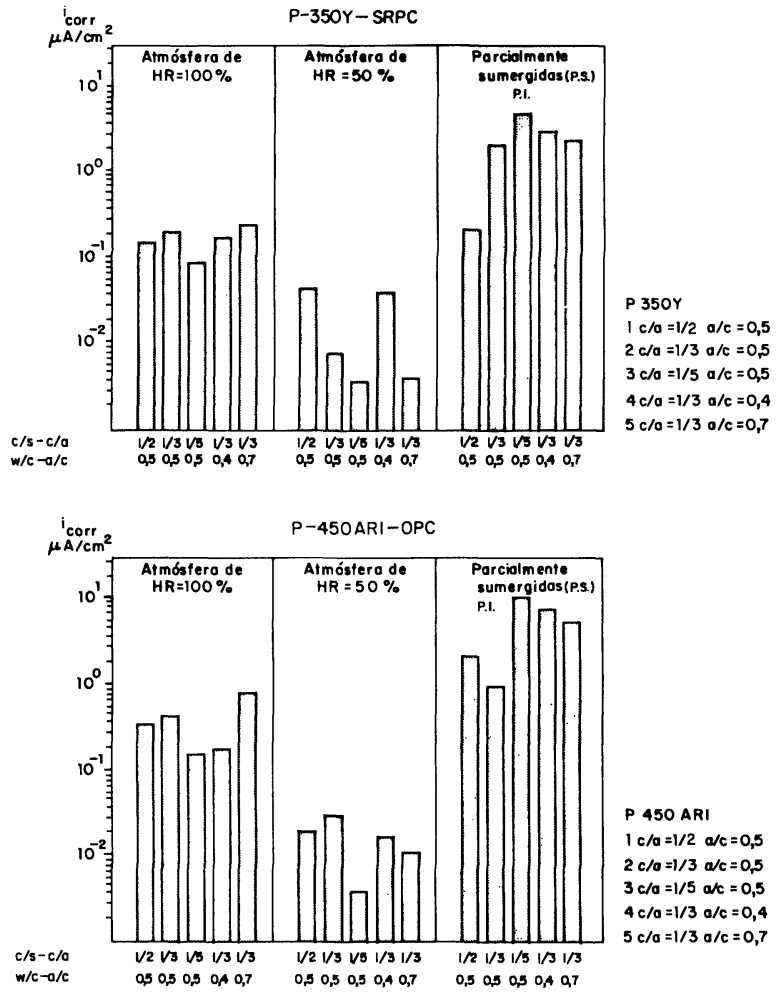

Fig. 4.- Influencia de la dosificación del mortero en la velocidad de corrosión de armaduras embebidas en mortero carbonatado, $\mathrm{i}_{\text {corr }}$ a los 30 días de permanecer en cada humedad.

Effect of the mortar composition in the corrosion rate of rebar embedded in carbonated mortar. $i_{\text {corr }}$ after 30 days in each humidity. $(c / s=1 / 3$ and $w / c=0.4)$, and $(c / s=1 / 3$ and $w / c=0.7)$, made with $O P C$ and SRPC

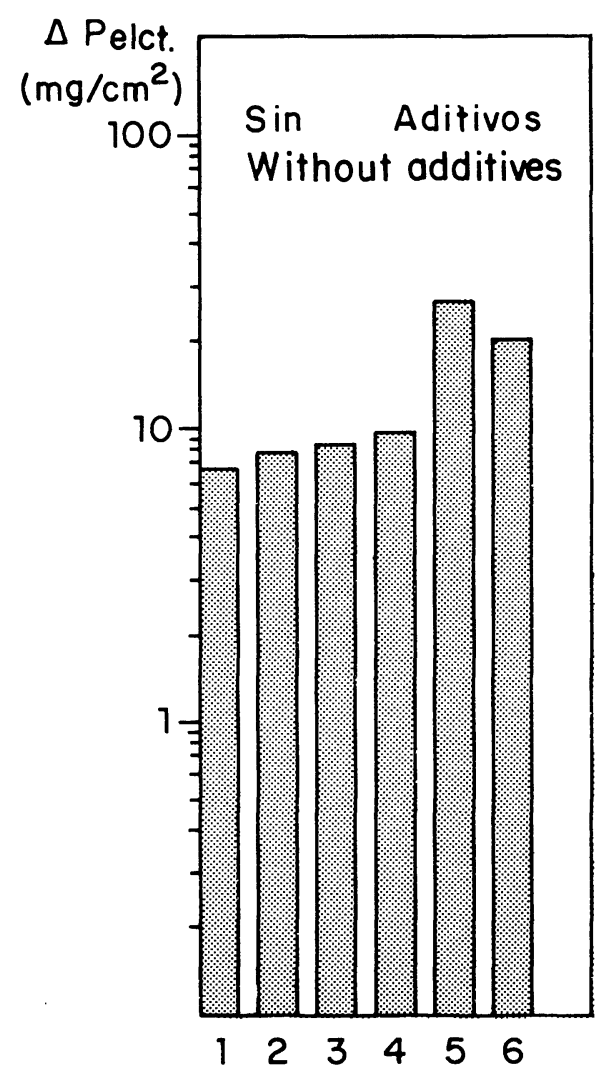

Fig. 5.-Perdida de peso electroquimica sufrida por las armaduras embebidas en los distintos tipos de mortero de cemento ensayado: 1) P-450 ARI, 2) P-350 Y, 3) P + $+30 \%$ cenizas, 4) S-II 350,5$)$ PUZ-350 y 6) cenizas, con $\mathrm{c} / \mathrm{a}=1 / 3, \mathrm{a} / \mathrm{c}=0,5$.

Electrochemical weight loss of the rebars in the different mortar used: 1) OPC, 2) SRPC, 3) OPC + $30 \%$ FAC, 4) SC, 5) $P O Z Z C$, 6) FAC, $c / s=1 / 3, w / 0=0.5$.

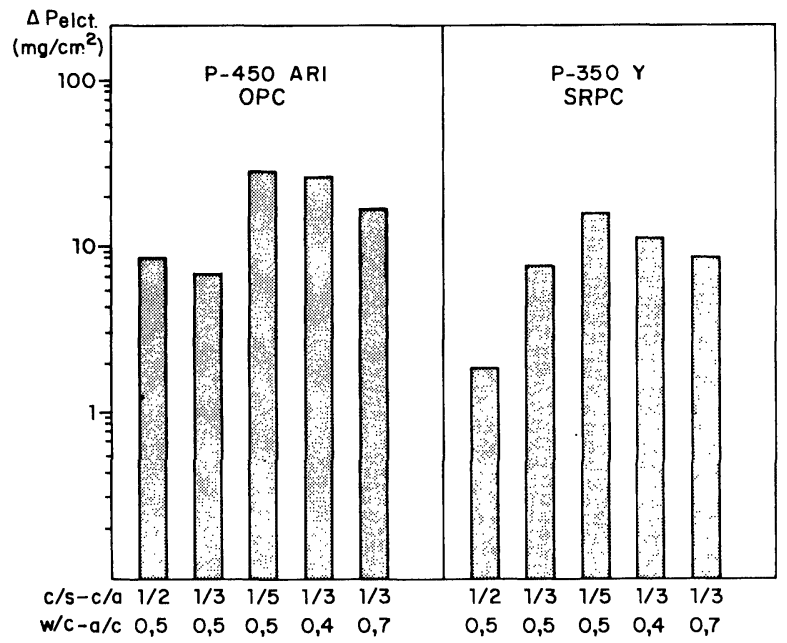

Fig. 6.-Pérdida de peso electroquímica de los aceros embebidos en mortero carbonatado con distintas dosificaciones.

Electrochemical weight loss o rebars embedded in carbonated mortar of different proportions. 
La morfología del ataque producido en las probetas ensayadas indica que éste tiene lugar sobre toda la superficie de ensayo, ésta estaba recubierta por óxidos de color pardo y en algunos puntos también negro. Una vez limpias de óxido, aunque había ataque generalizado en toda la superficie, éste era más pronunciado en unos puntos que en otros.

\section{DISCUSION}

Debido a la reacción del $\mathrm{CO}_{2}$ con los productos hidratados del cemento, se produce un fuerte descenso del $\mathrm{pH}$ en la solución de los poros que encierran el mortero. Cuando el $\mathrm{pH}$ de esta disolución llega a valores $\leq 8$, la armadura no puede permanecer pasiva y la capa de óxidos pasivante, que inicialmente la recubre, se disuelve dejándola desprotegida. Posteriormente y bajo condiciones adecuadas puede continuar corroyéndose. De esta manera se explicaron ya en anteriores trabajos (11), los cambios detectados en las variables $i_{\text {corr }}$ y $E_{\text {corr }}$ de la armadura, durante el proceso de carbonatación acelerada al que se han sometido las probetas.

Finalizada la reacción del $\mathrm{CO}_{2}$ con la materia carbonatable del cemento (parte de ella puede permanecer no accesible en un proceso de carbonatación acelerada, a menos que éste sea suficientemente prolongado), si las probetas se siguen conservando en la cámara al $60 \%$ H.R., comienzan a sufrir un descenso del peso, ya que no son capaces de captar más $\mathrm{CO}_{2}$ y el agua formada en los poros, simultaneamente con el $\mathrm{CaCO}_{3}$, se va evaporando. Esta evaporación se detecta por el relativo ennoblecimiento del potencial y descenso de la $i_{\text {corr }}$ que aparece al final del período de carbonatación.

Posteriormente, al someter los morteros carbonatados a distintas humedades relativas de conservación, las $\mathrm{i}_{\text {corr }}$ medidas son función fundamentalmente de la humedad relativa ambiental, como ya se indicó con anterioridad (10). La humedad disminuye la resistividad y facilita los procesos de corrosión.

El acero embebido en mortero carbonatado responde como si estuviera directamente expuesto a la atmósfera, pero con el agravante de estar rodeado de un mortero no protector que actúa a modo de esponja, que mantiene la humedad más tiempo que si el acero estuviera directamente en contacto con el aire. Es bien conocido que el hormigón adsorbe agua muy rápidamente y lo suelta mucho más despacio. Este comportamiento se aprecia en la figura 2, donde las $i_{\text {corr }}$ aumentan bruscamente al

\section{DISCUSSION}

When $\mathrm{CO}_{2}$ reacts with the hydrated products of cement a dramatic decay of the $\mathrm{pH}$ in the solution trapped in the pores of the concrete takes place. If the $\mathrm{pH}$ of the solution reaches values $\leq 8$, the rebars cannot continue passives becouse the passive oxide film which protect the steel is dissolved.

Later if the rebars are kept in favourable wet conditions they continue corroding. This explains the changes detected on the variables $i_{c o r r}$ and $E_{\text {corr }}$ during the accelerated carbonation process of the mortar specimens (11).

However, when $\mathrm{CO}_{2}$ reaction with mortar finishes (a portion of cement may remain unreacted in an accelerated carbonation process if this is not long enough) and the specimens continue in the carbonation chamber at $60 \%$ R.H., the weight of the specimens start to decrease because they are not able to react with more $\mathrm{CO}_{2}$ and the water formed in the pores simultaneously with $\mathrm{CaCO}_{3}$ is evaporated.

This provoques a shift in the potential of the rebars to more possitive values and a decrease in the $i_{\text {corr }}$. Then, when the carbonated specimens are held to consecutive changes of the ambient humidity, the $i_{\text {corr }}$ of the rebars depends on the relative humidity as it was previously pointed out (10). When the humidity increases the resistivity of the mortar decreases and it enables the corrosion process.

The steel embedded in carbonated mortar behaves worse than in direct contact with the atmosphere, because the no protective mortar acts like a sponge and it keeps the humidity for longer time than if the steel were directily in contact with the air. it is well known that the cocrete absorbs water quickly but it gets out slower.

This behaviour is appreciated in figure 2, where the $i_{\text {corr }}$ suddenly increases when the humidity also does, but it slowly decreases when the humidity changes to lower values. 
incrementarse la humedad ambiental, pero desciende paulatinamente cuando el cambio es hacia menores contenidos de la misma.

\section{Influencia del tipo de cemento}

El uso de adiciones a los cementos como: escorias, cenizas volantes o puzolanas, afectan entre otros parámetros a la reserva alcalina resultante del proceso de hidratación que queda en general muy reducida. Esto hace que en el fenómeno de carbonatación, la cantidad de materia carbonatable sea menor en un mortero con adiciones (a igualdad del resto de las variables) que en un mortero de cemento portland puro. Sin embargo en condiciones naturales, como los cementos con adición, si están bien curados, suelen dar lugar a hormigones menos penetrables; no siempre se produce una llegada más rápida del frente carbonatado en los morteros fabricados con dichos cementos de adición.

En relación con la naturaleza del cemento la otra variable a considerar es el contenido en álcalis del mismo, ya que como se pudo comprobar en otros trabajos (12), la presencia de $\mathrm{Na}^{+}$y K $\mathrm{K}^{+}$amortigua el fenómeno de carbonatación y podría dar lugar a valores finales de $\mathrm{pH}$, de la fase acuosa intersticial, más alcalinos, alrededor de 9-10, que cuando la proporción de álcalis es baja, que sería alrededor de 7 . Pero también hay que señalar que en el caso de los cementos de adición no todos los álcalis son solubles en agua, por lo que una interpretación simplista a partir de los análisis químicos no se puede realizar, excepto en el caso de los portland puros ( $P-Y$ y P-450 ARI). Entonces contemplando la figura 5 no se aprecia ninguna diferencia significativa entre ambos cementos, aunque sin embargo la figura 6 parece indicar una mayor corrosión en las barras embebidas en mortero fabricado con el P-450 ARI (el más alto en álcalis).

De estos dos resultados diferentes, la consecuencia a extraer es que no parece que el contenido en álcalis influencie significativamente la corrosión del acero o en todo caso la influencia no se puede deducir de los presentes resultados.

La única tendencia sistemática encontrada, digna de ser señalada, son las mayores $i_{\text {corr }}$ medidas en los casos de los cementos PUZ y cenizas ( $N .^{\circ} 5$ y 6 ) a las que hasta el momento no se les ha encontrado más razones coherentes, ya que el cemento $\mathrm{N} .^{\circ} 3$ también contiene cenizas volantes y sin embargo presenta velocidades de corrosión del mismo orden que los portland.

Todo ello lleva a deducir que no parece que la

\section{Effect of the type of cement}

The use of blended materials in portland cement as: slag, Fly ash or pozzolans, affects, in spite of others parameters, to the alkaline content which results from the hydration process. Therefore, the amount of carbonatable material is lesser in blended cements than in portland ones. However, by other hand in natural conditions, cements with blended materials are less penetrable if they are well cured and not always the carbonation front reachs the rebar quicker than in mortars made with OPC cements.

Another variable to be considered related to the type of cement, is the alkaline content. It was proved in previous papers (12) that the presence of $\mathrm{Na}^{+}$and $\mathrm{K}^{+}$makes slower the carbonation fenomenon and higher values of $\mathrm{pH}$ at he end of the carbonation (between 9-10) are detected. If an excess of $\mathrm{CO}_{2}$ is used then the final $\mathrm{pH}$ could be around 7. However it is also important to point out that alkalies in blended cements are not completely soluble in water, so that a simple deduction from the chemical analysis of the cements to try to predict the behaviours is not possible except for OPC cements. Looking at figure 5 any significative differences between both cements do not exit, although in figure 6 slightly higher corrosion on rebars embedded in mortar made with OPC (cement with higher alkaline content) is detected.

From those results it may be drawn that the alkaline content does not significatively affect the corrosion o the steel or if it does it is not possible to deduce from the results presented here.

The only systematic trend to state is the higher $i_{\text {corr }}$ measured for pozzolan and fly ash cements ( $N .^{\circ} 5$ and 6 ) but for the moment it has not been found any explanation for that because cement $n .^{\circ} 3$ has also fly ashes but presents similar corrosion rate that the OPC one.

All of this seems to indicate that the nature of 
naturaleza del cemento o su contenido en álcalis influyan de forma significativa una vez carbonatado el mortero. Más bien todo parece indicar que una vez despasivada la armadura ésta se corroe o no, fundamentalmente en función de la humedad de los poros.

\section{Influencia de la composición del mortero}

En cuanto a la dosificación en cemento y la relación a/c empleada, sí parece que la primera tenga un papel importante, sobre todo cuando se conjuga con una relación a/c adecuada.

Se destaca lo de "adecuada", porque no es lo mismo que una relación a/c baja, ya que una relación a/c baja puede dar lugar a problemas en la compactación que llevan a morteros más porosos y menos protectores, como ha ocurrido en los presentes ensayos con el mortero $1 / 3$ y 0,4 que ha presentado $i_{\text {corr }}$ más elevadas que el 1/3 y 0,5. También ha dado peores resultados el mortero $1 / 3$ y 0,7 , y claramente se destaca como el menos protector el mortero $1 / 5$ y 0,5 .

Parece pues, que la porosidad sería un parámetro influyente en la cinética de corrosión del acero en morteros carbonatados; lo que concuerda con que las condiciones de inmersión parcial sean las de máxima agresividad medida. Este efecto de la porosidad está basado en que morteros más porosos presentan resistividades eléctricas menores permitiendo pues velocidades de corrosión superiores. Esta relación lineal entre porosidad y resistividad eléctrica se ha establecido en otros trabajos (13) (14).

En los presentes ensayos se confirma su influencia ya que en condiciones de inmersión parcial, donde las velocidades de corrosión medidas fueron muy elevadas, las resistividades del electrólito fueron las más bajas; unas cinco veces inferiores $\left(\simeq 10^{3} \Omega\right)$ en las dosificaciones $(c / a=1 / 3, a / c=0,4)$ $(c / a=1 / 3, a / c=0,7)$ y $(c / a=1 / 5, a / c=0,5)$ respecto de las relaciones $(c / a=1 / 2$, $a / c=0,5)$ y $(c / a=1 / 3, a / c=0,5)$ que fueron del orden de $5 \times 10^{3} \Omega$. Estas dos últimas dosificaciones de mortero dieron lugar a las más bajas pérdidas de peso electroquímicas. Se sigue confirmando, por tanto, que la resistencia eléctrica del electrólito controla en alguna forma aún no bien establecida, la velocidad de corrosión de las armaduras.

\section{CONCLUSIONES}

De los resultados del presente estudio se cement or its alkaline content do not affect corrosion in a significative manner when the mortar is carbonated. When the rebar is depassivated due to the carbonation of the cover, the steel corrodes or not mainly depending on the humidity in the pores.

\section{Effect of the mortar composition}

By other hand the mortar composition and the $w / c$ ratio used seems to have a more important role on corrosion rebars in carbonated mortar the lower corrosion was detected in the most compact mortars, thus, in those mixed with the adequate $\mathrm{w} / \mathrm{c}$ ratio. It is important to poin out "adecuate" and not the lower $w / c$ ratio, because this may give rise to problems in compaction, which would bring to mortar more porous and therefore less protective, as it has happened in present tests with the mortar 1/3 and 0.4 which has presented higher $i_{\text {corr }}$ than the mortar $1 / 3$ and 0.5 . Also has given worse results the mortar $1 / 3$ and 0.7 and the mortar $1 / 5$ and 0.5 clearly also appears as less protective.

It seems that the porosity would be a parameter which has an important influence in the kinetic of corrosion of the steel in carbonated mortar. A higher porosity means a higher amount of pore solution in the same volume of mortar and therefore a lower electrical resistivity which allows a higher corrosion rate.

Lineal relationship between porosity and electric resistivity has been stablished in other papers (13) (14). In this paper this influence is confirmed, because under partial immersion where the corrosion rate measured presented the highest values, the resistivity of the electrolite had the lowest ones $\left(\simeq 10^{3} \Omega\right)$. They were about five times lower for the proportions $(c / s=1 / 3, w / c=0,4)(c / s=1 / 3, w / c=0,7)$ and $(c / s=1 / 5, w / c=0,5)$ compared with those obtained in $(c / s=1 / 2, w / c=0,5)$ and $(c / s=1 / 3, w / c=0,5)$ which were about $5 \times 10^{3} \Omega$. The last two proportion of mortar give rise the lowest electrochemical weights loss. Thus, this may be considered as another confirmation corrosion rate of the rebars, in some way still not stablished.

\section{CONCLUSIONS}

From the results of the test done here it is 
pueden extraer las siguientes conclusiones:

1. Se confirma nuevamente que la carbonatación del recubrimiento de hormigón que rodea a la armadura provoca la destrucción de la capa pasiva de ésta, pero son necesarias humedades ambientales elevadas para que el proceso de corrosión llegue a hacer peligrar la vida de la estructura. La humedad resulta el parámetro que más determina la velócidad de corrosión.

2. La naturaleza del cemento empleado influye en la cantidad de $\mathrm{CO}_{2}$ combinado por la materia carbonatable del mortero, pero no parece tener influencia en el progreso posterior de la cinética de corrosión.

3. La composición del mortero sí tiene una influencia que se ha podido discriminar en los presentes resultados. Así, ha resultado la peor dosificación la de $1 / 5$ y 0,5 , pero no puede afirmarse que sean siempre más favorables las relaciones a/c más bajas. La mejor situación de compacidad la aporta un mortero de elevado contenido en cemento y "adecuada" relación $a / c$, que permita una buena compactación. possible to get out the following conclusions:

1. It is confirmed again, that the carbonation of the mortar provoques the dissolution of the passive film, however high humidities are necesary to affect significatively the corrosion process. Humidity results a parameter that determines the corrosion rate.

2. The nature of the cement used influences in the amount of $\mathrm{CO}_{2}$ combined, but it does not seem to have influence in the ulterior progress of the corrosion.

3. However, the composition of the mortar has an influence. The most compacts mortars (the highes resistivity) present the lowest corrosion rates in the wet periods. It is confirmed a relationship between resistivity (related in some way with porosity) and the corrosion rate.

\section{B I B LIOGRAFIA}

(1) P. SCHIESSL: Corrosion of reinforcement-durability of concrete structures, CEB, RILEM, Mayo (1983) Copenhague.

(2) F. SCHRÖDER y H. G. SMOLCZYK: Proceeding of 5. int Symposium on the chemistry of cement, pg. 144 (1968) Tokio.

(3) D. BUNNET y M. RUBAUD: Cahiers du centre scientifique et technique du batiment, n. ${ }^{\circ} 168$, Coh. 1371, Abril (1976).

(4) R. BAKKER: Corrosion of steel in concrete, state of the art. Report RILEM Tecnical Commite 60 - CSC (1986).

(5) D. W. S. HO y R. K. LEWIS: Internt. Conf. fly ash, silica fume slag and natural puzzolans in concrete, Sp. 79-17, pg. 333-346 (1983) Detroit.

(6) M. STERN y A. L. GEARY: J. Electrochem Soc., Vol. 104, pg. 56 (1975).

(7) C. ANDRADE y J. A. GONZALEZ: Werkstoff. Korros. Vol. 29, Pg. 515 (1978).

(8) C. ANDRADE y J. A. GONZALEZ: $5 .^{a}$ Asamblea del CENIM, Sep. (1981).

(9) C. ANDRADE, V. CASTELO, C. ALONSO y J. A. GONZALEZ: Corrosion of rebars in concrete, Edt. V. Chaker, ASTM 906, pg. 43 (1986).

(10) J. A. GonZALEZ, S. ALGABA y C. ANDRADE: Br. Corrs. J. Vol. 15, pg. 15 (1980).

(11) J. A. GONZALEZ, C. ALONSO y C. ANDRADE: Corrosion of reinforcement in concrete construction. Edt. A. P. Crane, Cap. 11, pg. 159 (1983).

(12) C. ANDRADE, C. ALONSO, P. SANTOS y A. MACIAS: 8th Intern. Congress on the chemistry of cement. Sept. (1986) Rio de Janeiro.

(13) A. MOLINA, C. ANDRADE, C. ALONSO y J. A. GONZALEZ: Rev. Téc. Ing. Univ. Zulia, Vol. 8, n. 2 (1985).

(14) C. ALONSO, C. ANDRADE y J. A. GONZALEZ: Katharine and Bryant Mather Int. Conf. on Concr. Durability, Abril (1987) U.S.A. 